\title{
Optimization of Moringa Oleifera Leaf Extraction and Investigation of Anti Breast Cancer Activity with the Leaf Extract
}

\author{
Nazia Hossain ${ }^{*}$, M. E. S. Mirghani ${ }^{2}$, Raha Bt. Raus ${ }^{3}$
}

${ }^{1,2,3}$ Department of Biotechnology-Biochemical Engineering, Faculty of Engineering, International Islamic University Malaysia (IIUM), Gombak, MALAYSIA

${ }^{1,2}$ International Institute for Halal Research and Training (INHART), IIUM, Gombak, MALAYSIA

*Corresponding Contact:

Email: bristy808.nh@gmail.com

\begin{abstract}
Moringa oleifera ( $M$. oleifera) has been considered as medicinal plant and food substance since ancient times. Nowadays various therapeutic effects of $M$. oleifera such as antimicrobial, anticancer, anti-inflammatory, antidiabetic, and antioxidant effects have been successfully investigated. In this study, the main objective was to optimize $M$. oleifera leaf-methanol extraction using Design of Experiment (DoE) software with response surface methodology in terms of temperature and incubation time by sonication. The other objective was to investigate anti-cancer activity (breast cancer cell: MCF-7) by $M$. oleifera methanol extraction incorporation with microtitrate tetrazolium (MTT) assay. In this research, the optimum condition for leaf extraction was found to be temperature $50^{\circ} \mathrm{C}$ and incubation time 45 min with medium frequency at sonication and it obtained $88.39 \%$ cancer cell growth inhibition by this condition. Extracted leaves inhibited MCF-7 cell line with $87.13 \%$ in average at wavelength A570nm.
\end{abstract}

Key words

Moringa oleifera leaves extract, Breast Cancer Inhibition, Anti-cancer Activity, Optimization, Response Surface Methodology

\section{INTRODUCTION}

Breast cancer is the most leading cause of women mortality in whole world. 7.6 million people are dying worldwide by cancer every year where 1.38 million of breast cancer cases, the highest death rate cause. The World Health Organization (WHO) of the United Nations (UN) projects that without immediate action, the global number of deaths from cancer will increase by nearly $80 \%$ by 2030 , with most occurring in low and middle income country (Abeloff etal, 2008; Globocan, 2008). 
DNA carries genes that are the blueprints for protein produced in the body and proteins work to suppress the growth. But sometimes mutation occurs in some particular genes because of radiation, Ultra-violet radiation, smoking, alcohol or other carcinogens what can cause the abnormal production of proteins and the combination of these abnormal proteins create cancer as a result (Blask, 1988). Cancer cells flock and build up tumors that may compress, invade and cause destruction of normal tissues. Sometimes, cells break away from the tumor and flow through the bloodstream or the lymph system to others organs of body parts and settle down somewhere and stay permanently to build up 'colony tumor' and the cells start to grow over there. This new site of tumor forming is known as 'Metastasis' (American Society of Clinical Oncology, 2009; Shishodia, 2004).

Plant-derived substances have recently achieved great interest owing to their versatile applications such as Moringa oleifera of monogenic family, the Moringaceae. It is a well famous plant cultivated in tropical or sub-tropical areas such as Himalayan tracts of India, Pakistan, Bangladesh, Afganistan, Malaysia, Indonesia, Egypt, Sudan, Nigeria, Chad, Somalia, Tanzania and others. It is known as 'drumstick tree', 'golden shower tree', 'horseradish tree', 'ben oil tree' and 'benzoil tree' [10]. The leaves contain nutrients especially essential amino acids, vitamins, minerals, $\beta$-carotene, benzyl isothiocyanate, niazimicin, pterygospermin, benzyl isotiocyanate, benzyl glucosinolate. Besides nutritional benefits, M. oleifera is used for the treatment of rheumatism, ascites, infection, hiccough influenza and internal abscess (Farooq, 2007).

Few researches were gone through different types of cancer cells incorporation with ethanol extraction of Moringa leaves and they showed strong cytotoxicity against cancer cells such as hepatocarcinoma and coloractal adenocarcinoma. That's why Moringa leaves extraction was experimented to inhibit breast cancer cells (MCF-7) in this study [5]. Compare to ethanol extraction, methanol extraction is easier, less time consuming. Methanol was normally preferred in this study as the organic solvent since it is more polar as compared to other types of alcohol such as ethanol, acetone etc and in many cases methanol extraction produced the best extraction results. Especially to extract leaves in different conditions by sonication (cell disruption by ultra-sound), only methanol showed stable extraction where ethanol and acetone caused cover-bursting effect with high temperature (King, 1984).

To mention, differents parts of $M$. oleifera have been experimented to investigate its' effect on various types of diseases. Nevertheless, there is limited research for M. oleifera leaf extract on anti breast cancer cell and there is no methanol leaf extraction on breast cancer cell has been experimented. So, the goal of this research was to investigate anti-breast cancer activity of Moringa leaves with methanol extraction by sonication method and optimize it with different conditions run by Design of Experiment (DoE) optimization software (Box, G. a.; Charoensin, 2014).

\section{Materials AND Methods}

Materials: Fresh Moringa oleifera leaves were collected from a garden near to Terminal Putra LRT station, Gombak, Kuala Lumpur, Malaysia. Experimented samples both celllines breast cancer cell-line (MCF-7) \& normal cell-line (VERO) and the chemicals accutase, phosphate buffer solution (PBS) 10x solution, DMEM (Dulbecco Modified Eagle Medium) powder, $70 \%$ ethanol for sterilization, Fetal Bovine Serum (FBS), dimethyl sulphoxide (DMSO), $\mathrm{NaOH}$ powder or pellet, $\mathrm{HCl}$, Sodium carbonate powder, tryptophan blue dye \& MTT assay were collected from IIUM cell \& tissue laboratory. 
Methods: Fresh Moringa oleifera leaves were washed with clean water, dried, ground and stored for experiment. The Moringa leaf-methanol extraction process was optimized with 11 runs done by Design Expert software 6.0.8 (DOE) using response surface metodology. Extraction (11 runs) of the leaves was done by sonication method through an ultrasonic bath at medium frequency at $40-60^{\circ} \mathrm{C}$ for $30-60$ minutes. $3 \mathrm{~g}$ of each dried sample was dissolved in $30 \mathrm{ml}$ of methanol. The crude extract was isolated through vacuum filtration and rotary evaporation process. Then extract was transferred to a $15 \mathrm{ml}$ tube and $10 \mathrm{ml}$ DMSO was added to preserve. Normal cell-line (VERO) and Breast cancer cell-line (MCF7) were cultured through stored frozen cells thawing, media change, sub-culturing monolayer cells and cell counting respectively. The cells were seeded at $2 \times 10^{5}$ cells per ml for breast cancer cell in a 100 $\mu$ l of media (DMEM 90\% and serum 10\%) per well in 96 well plates. Both cell-lines were incorporated with extracted Moringa leaves in different plates and finally MTT assay was added on the incorporation and the absorbance at A570 nm was recorded immediately by an ELISA plate reader. Then the data was analyzed.

\section{RESULT}

\section{Optimization of Process Conditions by Design of Expert (DOE)}

To optimize the cancer cell inhibition it in terms of temperature and incubation time. 11 experiments were run as designed using Design of Expert (DOE) software, version 6.0.8 to attain its optimal yield at $50^{\circ} \mathrm{C}$, at an optimal incubation time of 45 minute.

\section{Anova Analysis}

\section{Response: Cell growth Inhibition}

Analysis of Variance (ANOVA) for Response Surface Quadratic Model was used to determine whether the model is significant or not. The coefficient $p$-value for linear, quadratic and interaction terms are shown in Table 1.

Table 1: Sequential Model Sum of Squares

\begin{tabular}{|l|c|c|c|c|c|l|}
\hline \multicolumn{1}{|c|}{ Source } & $\begin{array}{c}\text { Sum of } \\
\text { Squares }\end{array}$ & $\mathbf{d f}$ & $\begin{array}{c}\text { Mean } \\
\text { Square }\end{array}$ & F value & $\begin{array}{c}\text { P value } \\
\text { Prob > F }\end{array}$ & \\
\hline Model & 163.58 & 5 & 32.72 & 22.79 & 0.0019 & Significant \\
\hline A-Temperature & 001.68 & 1 & 01.68 & 01.17 & 0.3289 & \\
\hline B-Incubation & 088.26 & 1 & 88.26 & 61.49 & 0.0005 & Significant \\
\hline AB & 003.70 & 1 & 03.70 & 02.58 & 0.1692 & \\
\hline $\mathbf{A}^{\mathbf{2}}$ & 019.11 & 1 & 19.11 & 13.31 & 0.0148 & Significant \\
\hline $\mathbf{B}^{\mathbf{2}}$ & 064.59 & 1 & 19.11 & 45.00 & 0.0011 & Significant \\
\hline Residual & 007.18 & 5 & 64.59 & & & \\
\hline Lack of fit & 004.50 & 3 & 01.50 & 01.12 & 0.5042 & Not Significant \\
\hline Pure Error & 002.68 & 2 & 01.34 & & & \\
\hline Core Total & 170.76 & 10 & & & & \\
\hline
\end{tabular}

The Model F-value of 22.79 implies the model is significant. There is only a $0.19 \%$ chance that a "Model F-Value" this large could occur due to noise. Values of "Prob > F" less than 0.0500 indicate model terms are significant. In this case $\mathrm{B}, \mathrm{A}^{2}, \mathrm{~B}^{2}$ are significant model terms. Values greater than 0.1000 indicate the model terms are not significant.

The "Lack of Fit F-value" of 1.12 implies the Lack of Fit is not significant relative to the pure error. There is a $50.42 \%$ chance that a "Lack of Fit F-value" this large could occur due to noise. 
Table 2: Model characteristics

\begin{tabular}{|c|c|c|c|}
\hline Std. Dev. & 1.20 & R-Squared & 0.9580 \\
\hline Mean & 87.13 & Adj R-Squared & 0.9159 \\
\hline C.V.\% & 1.37 & Pred R-Squared & 0.7142 \\
\hline PRESS & 48.81 & Adeq Precision & 13.743 \\
\hline
\end{tabular}

The "Pred R-Squared" of 0.7142 is not as close to the "Adj R-Squared" of 0.9159 that was very much expected. A ratio greater than 4 is desirable (Box, G. a.). Here, the ratio of 13.743 indicates an adequate signal for successful optimized design. Mean is the average value of all outcomes and here mean cancer cell growth inhibition percentage by Moringa oleifera leaves extract is 87.13 what is very positive with the project.

C. V. $\%=\frac{\text { Std. Dev }}{\text { Mean }} \times 100 \%$

In this project, C.V. \% was very low 1.37 what good sign for result stability. The predicted residual sum of squares (PRESS) was 48.81 that was less than 50. The equations showed below followed by software auto-calculation to determine cell inhibition amount.

\section{Final Equation in Terms of Coded Factors:}

Cell growth Inhibition $=\quad+88.39-0.53 * \mathrm{~A}-3.84 * \mathrm{~B}-0.96 * \mathrm{~A} * \mathrm{~B}+2.75 * \mathrm{~A}^{2}-5.05^{*} \mathrm{~B}^{2}$

Final Equation in Terms of Actual Factors:

Cell growth Inhibition $=+111.33118-2.5109 *$ Temperature $+2.08478 *$ Incubation Time $-6.41361 \mathrm{E}-00 *$ Temperature *Incubation Time $+0.027466 *$ Temperature $^{2}-0.022442 *$ Incubation Time ${ }^{2}$

\section{Diagonostic}

In the diagonostic, Figure 1 (predicted vs. actual response) showed that the distribution of points are closed to linear line $\left(R^{2}=0.9580\right)$ and Figure 2 shows the 3 dimensional view of the whole optimization process and optimized point as well.

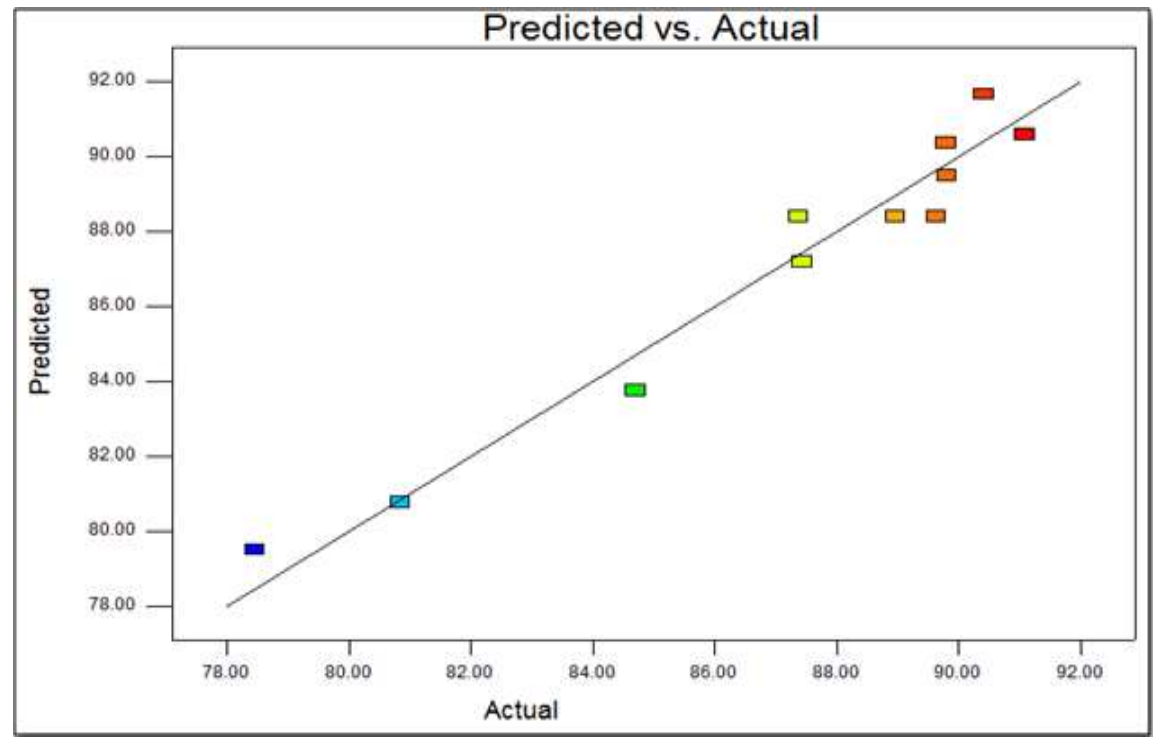

Figure 1: Predicted vs. Actual values 

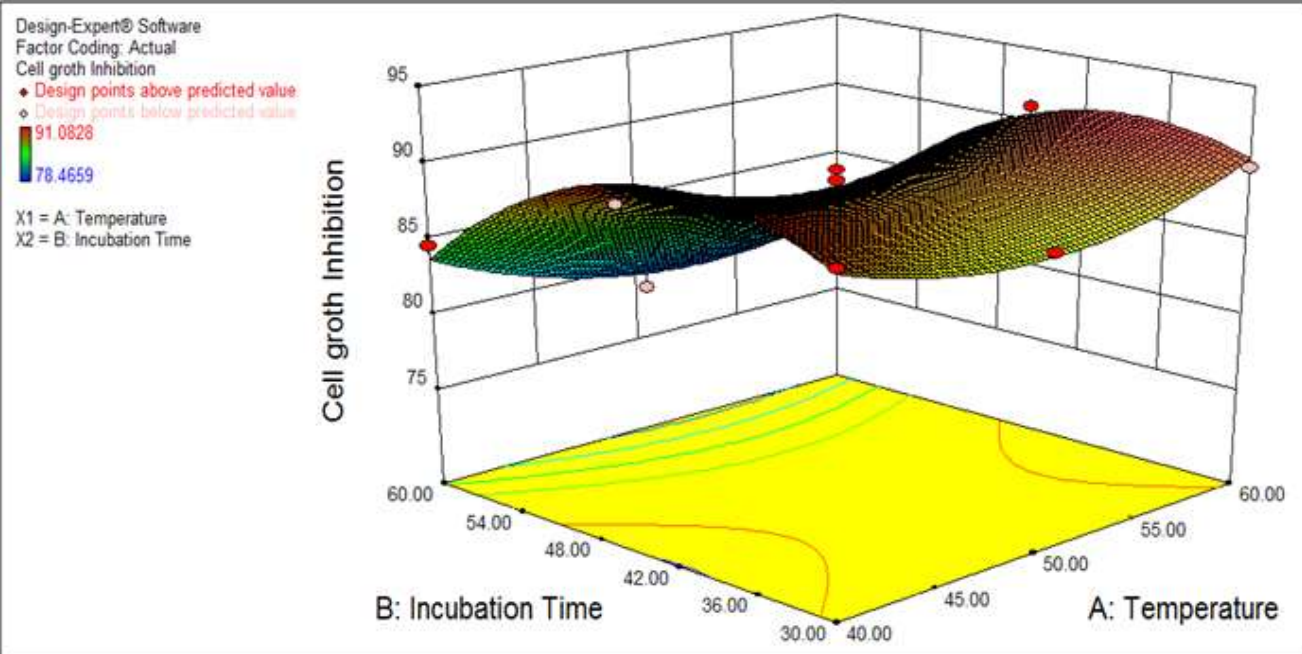

Figure 2: 3D view plot for desirability

\section{EXPERIMENT RESULT}

The results were taken using ELISA microplate reader at $570 \mathrm{~nm}$. In order to validate the result obtained from triplicate for each run. Thus using the same concentration range, three 96 well plates were done for each run of each cell-line. Average was taken to obtain the final value and cell viability and cell growth inhibition percentage for both types of cells were calculated by the equations:

Growth $=\frac{O D_{\text {treated cells }}}{O D_{\text {untreated cells }}} \times 100 \%$

Growth inhibition $=100 \%-\frac{O D_{\text {treated cells }}}{O D_{\text {untreated cells }}} \times 100 \%$

OD untreated cells $_{=}$Media with cells without extract

$\mathrm{OD}$ treated cells $=$ Media with cells with extract

For normal cell-line (VERO), four experiments were done with different conditions based on DoE table to check $M$. oleifera leaves extract affect normal cells or not. These all experiments showed normal cell inhibition by average cell inhibition $12.89 \%$ and in optimum extraction condition at temperature $50^{\circ} \mathrm{C}$ and incubation time 45 min with medium frequency, cell growth inhibition is $13.92 \%$.

Table 3: VERO cell-line growth Inhibition by different conditions

\begin{tabular}{|c|c|c|}
\hline Temperature $\left({ }^{\circ} \mathrm{C}\right)$ & Incubation Time (min) & Cell Growth Inhibition (\%) \\
\hline 50 & 45 & 19.40 \\
\hline 50 & 30 & 6.08 \\
\hline 40 & 60 & 12.17 \\
\hline 50 & 45 & 13.92 \\
\hline
\end{tabular}

There were 11 runs of experiments done on MCF-7 by Moringa leaves extract with different conditions based on time and temperature in terms of DOE table and analyzed the results. It is shown below. 
Table 4: Result Analysis by DOE

\begin{tabular}{|c|c|c|c|c|}
\hline Std & Run & $\begin{array}{c}\text { Factor 1 } \\
\text { A : Temperature }\left({ }^{\circ} \mathrm{C}\right)\end{array}$ & $\begin{array}{c}\text { Factor 2 } \\
\text { B : Incubation Time (min) }\end{array}$ & $\begin{array}{c}\text { Response 1 } \\
\text { Cell Growth Inhibition (\%) }\end{array}$ \\
\hline 3 & 1 & 50 & 60 & 78.4659 \\
\hline 4 & 2 & 60 & 60 & 80.8468 \\
\hline 2 & 3 & 60 & 30 & 89.7957 \\
\hline 1 & 4 & 40 & 30 & 89.7979 \\
\hline 6 & 5 & 60 & 45 & 91.0828 \\
\hline 9 & 6 & 50 & 45 & 87.3738 \\
\hline 5 & 7 & 40 & 45 & 90.4039 \\
\hline 10 & 8 & 50 & 45 & 89.6298 \\
\hline 7 & 9 & 50 & 30 & 87.4286 \\
\hline 3 & 10 & 40 & 60 & 84.6971 \\
\hline 11 & 11 & 50 & 45 & 88.9549 \\
\hline
\end{tabular}

Table 4 has shown high cancer cell growth inhibition by the extract. Average range of growth inhibition has been $80 \%-90 \%$ (mean value $87.13 \%$ ) with various conditions and in optimum extraction condition at temperature $50^{\circ} \mathrm{C}$ and incubation time 45 min with medium frequency, cell growth inhibition is $88.39 \%$.

\section{Discussion}

Optimization is a process to find an alternative with the most cost-effective or highest achievable performance under the given constraints by maximizing desired factors and minimizing undesired ones (Porter etal, 1997). To optimize our extraction process, DoE statistical analyses was used in this study where average PRESS was 48.81. Average PRESS value is the determination factor whether the model is over-fitted or under-fitted and PRESS value less than 50 is desired for optimized design (Box, G. a.). So, in this study optimized design was good overall. Besides, predicted vs. actual response showed that the distribution of points are closed to linear line $\left(R^{2}=0.9580\right)$. As much difference between the actual and predicted value is small, the result is counted better (Box, G. a.). In this design, difference for cell growth inhibition is very small in all runs that indicated the model is very good. These results proved that Response Surface Methodology statistical analysis fitted this experiment for optimizing the extraction condition.

Moringa oleifera extract work on different cancer cells in other research (Charoensin, 2014). In this research, breast cancer cell (MCF-7) growth inhibition was $87.37 \%$ in average that proved Moringa leaves extract was able to inhibit breast cancer cell with very high percentage in all kinds of condition parameters. When mixture was diluted with media the growth inhibition was also reduced, which evidenced that Moringa leaves extract was very strong against MCF-7 cell growth.

On the other hand, in this research, experiments on normal cell-lines (VERO) showed that Moringa extract inhibited VERO cell-line with small percentage (in average 12.89\%) too. But based on previous researches, it was proven that Moringa oleifera is good for health nutrition and its leaves extract usually does not kill normal cell-line (Farooq, 2007). In this case, it was suspected that the presence of methanol with leaves extract might affect this result by inhibiting normal cell growth. Because methanol is volatile alcohol similar with drinking alcohol and sometimes methanol causes toxicity that may cause metabolic acidosis, neurologic squealed and even death if ingested (King, 1984). To avoid this 
impurity, DMSO is recommended to use as solvent to re-dissolve the extract instead of methanol though using DMSO is expensive. For further research, dose responsive experiment should be recommended.

\section{CONCLUSION}

The Moringa leaves extraction optimum condition was found to be temperature $50^{\circ} \mathrm{C}$ and incubation time $45 \mathrm{~min}$ with medium frequency at sonication. After extraction, leaf extract and cancer cell lines with MTT assay were incorporated in $\mathrm{CO}_{2}$ incubator at $37^{\circ} \mathrm{C}$ (with $5 \%$ $\mathrm{CO}_{2}$ and $95 \%$ air) which is the physiological temperature. Moringa extraction inhibited cancer cell line with very high percentage. So, both of the objectives of this research were successfully achieved. It is strongly suggested that it could potentially be an ideal anticancer therapeutic candidate specific to cancer cells. These results suggested that extraction strategy adopted in this work could lead to several industrial applications and the potential therapeutic implications of the soluble extract from $M$. oleifera leaves extract in the treatment of various types of cancers.

\section{ACKNOWLEDGEMENT}

This work supported by the Cell and Tissue Laboratory at Biochemical-Biotechnology Engineering Department (BTE), Kulliyyah of Engineering (KOE), International Islamic University Malaysia (IIUM).

\section{REFERENCES}

Abeloff MD, Wolff AC, Weber BL, (2008). Cancer of the Breast. In: Abeloff MD, Armitage JO, Lichter AS, (Eds). Clinical Oncology. 4th ed. Philadelphia, Pa: Elsevier; 2008: pp.1875-1943.

American Society of Clinical Oncology. Clinical Cancer Advances 2009. Major Research Advances in Cancer Treatment, Prevention and Screening

Blask, S. M. (1988). Effects of the Pineal Hormone Melatonin on the Proliferation and Morphological Characteristics of Human Breast Cancer Cells (MCF-7) in Culture. Cancer Research , 48, 6121-6126.

Box, G. a. On the Experiment Attainment of Optimum Conditions. Journal of the royal Statistical Society Series $B, 13(1), 1-45$.

Charoensin, S. (2014). Antioxidant and anticancer activities of Moringa oleifera leaves. Journal of Medicinal Plant Research, 8(7), pp 318-325

Farooq Anwar, S. L. (2007). Moringa oleifera: A Food Plant with Multiple Medicinal Uses. Phytotherapy Research , 21, 17-25.

Globocan 2008. (2014, November 20). Breast Cancer Incidence and Mortality Worldwide, Cancer Incidence in Five Continents (C15) Volume I to X, International Agency for Research on Cancer, World Health Organization.

King, C. L. (1984). Factor Influencing Solvent Selection for Extraction of Methanol and Ethanol from Aqueous Solution. Ind.Eng.Chemical Process Des. , 1 (23), 109-115.

Mukherjee, A. \&. (2001). Advances in Cancer therapy with Plant based Natural Products , 8, 1467-1486.

Musa, E. N. (2012). An investigation of Anti-cancer activity of Moringa oleifera leaves. 1-5.

Porter S.C, Verseput R.P., Cunnigham C.R. (October, 1997)."Process Optimization using Design of Experiments". Pharm. Technology 1.

Shishodia, S. a. (2004). Guggulsteron Inhibits nf-kb and ikbs-kinase activation. Suppresses Expression of Anti-Apototic Gene Products and Enhances Apoptosis , 279.

Online Archive Link: $\underline{\text { https://abc.us.org/ojs/index.php/ei/issue/archive }}$ 